\title{
Optimization of Enhancement the Organizational Commitment through Developing Organizational Culture and Interpersonal Communication using Sequential Explanatory and SITOREM Methods
}

\author{
Widodo Sunaryo, Ali M. Basroh, Soewarto Hardhienata
}

\begin{abstract}
The organizational commitment is the important factor in the teaching process and for attaining educational goals. The condition of teacher's organizational commitment in this research setting is at the low level. The objective of this research is to find-out the way to enhance the organizational commitment through developing organizational culture and interpersonal communication. This research used the Sequential Explanatory Method combined with Scientific Identification Theory for Operational Research in Education Management (SITOREM).

By using the Sequential Explanatory Method, it was found that organizational culture had highly significant correlation with the organizational commitment $(r=0.809, p<0.01)$, and interpersonal communication had highly significant correlation with organizational commitment $(r=0.795, p<0.01)$, but both organization culture and interpersonal communication simultaneously had lower coefficient of correlation with organizational commitment $(r=0.895, p<0.01)$. By using the SITOREM, it was found that the low level of teacher's organizational commitment related to the low level of teacher's organizational culture and teacher's interpersonal communication.
\end{abstract}

Based on those results mentioned above, we proposed an action plan to optimize teacher's organizational commitment through an intensive training program to improve some selected indicators of organizational culture and interpersonal communication. The training program was designed for school principals and teachers in the research setting.

Index Terms: Organizational Commitment, Organizational Culture, Interpersonal Communication, Sequential Explanatory, SITOREM Methods.

\section{INTRODUCTION}

Teacher's organizational commitment becomes an important factor in the continuously teaching process and for attaining educational objectives. How a teacher is passionately teaching student in the classroom, willingness to working in a teamwork, providing loyalty to achieve school's objectives, or how he will pursuit long-term

Revised Manuscript Received on April 25, 2019.

Widodo Sunaryo, Graduate Program, Pakuan University, Bogor, Indonesia.

Ali M. Basroh, Graduate Program, Pakuan University, Bogor, Indonesia.

Soewarto Hardhinata, Graduate Program, Pakuan University, Bogor, Indonesia. professional development, all of those mentioned will determine the quality of his teaching process as well as his effort for attaining school educational objectives.

A preliminary survey that conducted to teachers in State High-Schools of Merangin District at Jambi Province, had some findings as follow: (a) $35.0 \%$ teachers had problem with the their passion and teamwork while doing their job, (b) $36.6 \%$ teachers had low aspiration about how to improve the quality of their job for attaining the school objectives, (c) $33.4 \%$ teachers felt that schools had given low facilities for doing their jobs, (d) $36.9 \%$ teachers had intention to find another jobs which could provide better benefits, (e) $28.4 \%$ teachers had problem in implementing the school values and rules while doing their jobs, and (f) $35.2 \%$ teachers had low sense of belongingness to the their own organization (school). The finding of this survey indicated the low organizational commitment of teachers in the research setting.

The research survey also found that many factors had influenced to teachers' organizational commitment, but some factors, like school organizational culture and teachers' interpersonal communication, had shown strong influence to teachers' organizational commitment. Those findings derived several research questions which were (a) is there any relationship between organizational culture and organizational commitment? (b) Is there any relationship between interpersonal communication and organizational commitment? (c) Is there any relationship between organizational culture and interpersonal communication simultaneously with organizational commitment?

Based on the discussion above, it can be formulated that the research objectives are to find the way to increase teachers' organizational commitment through identification of the relationship between organizational culture and interpersonal communication, and to find indicators of the research variables that have priority to improve immediately. 


\section{Optimization of Enhancement the Organizational Commitment through Developing Organizational Culture and Interpersonal Communication using Sequential Explanatory and SITOREM Methods}

\section{THEORETICAL REVIEW}

\section{A. Organizational Commitment.}

In 2015, Colquitt et al. stated that organizational commitment as the desire on the part of employee to remain a member of the organization. Organizational commitment influences whether an employee stays a member of the organization (is retained)

or leaves to pursue another job (turns over) [1]. There 3 types of organizational commitment which are (a) Affective Commitment, defined as a desire to remain a member of the organization due to an emotional attachment to, and involvement with, that organization, (b) Continuance Commitment, defined as a desire to remain a member of an organization because of an awareness of the costs associated with leaving it, and (c) Normative Commitment, defined as a desire to remain a member of an organization due to feeling obligation (you stay because you ought to).

In 2008, Greenberg and Baron defined that organizational commitment as the extent to which an individual identities and is involved with his or her organization and/or is unwilling to leave it [2]. Varieties of organizational commitment consists of (a) Continuance Commitment, defined as the strength of a person desire to continue working for an organization because he or she needs to do so and cannot afford to do otherwise, (b) Affective Commitment, defined as the strength of a person desire to work for an organization because he or she agrees with it and wants to do so, and (c) Normative Commitment, defined as the strength of a person desire to continue working for an organization because he or she feels obligations from others to remain there.

In 2010, Kreitner and Kinicki explain that organizational commitment is the extent to which an individual identifies with an organization and its goals [3]. The organizational commitment has three components as follows: (a) Affective Commitment refers to the employee's emotional attachment to, identification with, and involvement in the organization. Employee with a strong affective commitment continues employment with an organization because they want to do so. (b) Continuance Commitment refers to an awareness of the costs associated with leaving the organization. Employees whose primary link to the organization is based on continuance commitment remain because they need to do so. (c) Normative Commitment reflects a feeling of obligation to continue employment. Employees with high level of normative commitment feel that they ought to remain with the organization.

\section{B. Organizational Culture.}

In 2010, Edgar Schein defined organizational culture as pattern of shared basic assumption learned by a group as it solved its problem of external adaptation and internal integration, which has work well enough to be consider valid and, therefore, to be taught to new member as the correct way to perceive, think, and feel in relation to those problem [4]. Edgar Schein identified three level of organizational culture as follows (a) Artifacts, which consists of observed, visible and structures behavior and processes, (b) Espoused Beliefs and Values, which consists of ideals, goals, values,

aspirations, ideologies, and rationalizations, and (c) Basic Underlying Assumptions, which consists of unconscious, taken-for-granted beliefs and values.

Schermerhorn et. al defined organizational culture or corporate culture as the system of shared actions, values and beliefs that develops within an organization and guides the behavior of its member [5]. The organizational culture has 3 layers: (1) Observable Culture, it concerns about "the way we do thing around here", (2) Shared Values, it's a critical part in linking people together and can provide a powerful motivational mechanism for member of the culture, and (3) Common Cultural Assumption, these are the taken-for-granted truths that collections of corporate member share as a results of their joint experience.

Griffin and Moorhead defined organizational culture as the set of values that helps the organization's employees understand which action are considered acceptable and which are unacceptable [6]. This definition concerns about the values, those are (a) Strategic Values, are the basic beliefs about an organization's environment that shape its strategy, and (b) Cultural Values, are the values that employees need to have and act on for the organization to act on the strategic values.

Based on the definitions above mention, it can be synthesized that organizational culture is a pattern, system and understanding of the organization's basic assumption, shared values, beliefs, and consideration which actions (do thing) are acceptable and which are unacceptable. The components of culture consists of (a) consideration of accepted or unaccepted behavior, (c) Values and beliefs, and (c) Common Cultural or Basic Assumption and Understanding.

\section{Interpersonal Communication.}

Hellriegel and Slocum stated that interpersonal communication refers to a limited number of people who are usually in proximity to each other, use many sensory channels, and are able to provide immediate feedback [7]. An element of interpersonal communication consists of sender and receiver, transmitters and receptors, messages and channels, meaning and feedback.

Gibson et. al defined the interpersonal communication as communications that flow between individuals in face-to-face and group situations. The sender, the face-to-face situation, the receiver, and the feedback of communications become important aspects in an interpersonal communication process [8].

Robbins and Judges defined interpersonal communication as how members of a group transfer meaning between and among each other. They essentially relay on oral, written, and non-verbal communication [9]. The most effective interpersonal communication is a face to face communication on a consistent basis, as the best way to get information to and from employees.

Based on the definitions above mention, it can be synthesized that interpersonal communication is a communication that flow between individuals in face-to-face and group situations, relay on oral, written and non-verbal communication, 
and provide immediate feedback. Elements

of interpersonal communication consists of (a) sender and receiver, (b) transmitters and receptors, (c) messages and channels, and (d) meaning and feedback.

\section{THEORETICAL FRAMEWORK AND PRIOR RESEARCHES}

\section{A. Organizational Culture and Organizational Commitment.}

As Schein (2010: 18) stated that organizational culture concerned about how member of organization had the correct way to perceive,

think and feel in relation with organization's problem, and as Moorhead and Griffin (2014: 497) explained that organizational culture helped employees to understand which action are considered acceptable and which are unacceptable. All those statements lead to assumption that if the culture of an organization required employee to have highly organizational commitment, then it helped employees to understand that commitment to their organization is the correct or acceptable way.

A. Khalik, S. Hardhienata and Widodo Sunaryo (2016: 93-98) conducted an empirical research that analysis the relationship between organizational culture and organizational commitment. It had found that there was a positive and significant correlation between organizational culture and organizational commitment $(r=0.42, \mathrm{p}<0.05)$ [10].

\section{B. Interpersonal Communication and Organizational Commitment.}

As Hellriegel and Slocum (2011: 254) stated that interpersonal communication refers to people who are usually in proximity to each other, and as Robbins and Judges (2014: 164) defined interpersonal communication as how members of a group transfer meaning between and among each other. It means that interpersonal communication become a channel for employees to transfer, share, and build among them, their own organizational commitment.

Hassan Zarei Matin et al (2010: 387-398) conducted a research that investigated the relationship between interpersonal communication skills with organizational commitment. It had found that there was a positive and significant correlation between interpersonal communication skills and organizational commitment $(r=0.304, \mathrm{p}<0.01)$ [11].

Siburian (2013: 247-264) conducted a research which one of the research's objective is to investigate the relationship between interpersonal communication and organizational commitment. It had found that there was a positive and significant correlation between interpersonal communication and organizational commitment $(r=0.64$, $\mathrm{p}<0.00)$ [12]

\section{Organizational Culture, Interpersonal Communication and Organizational Commitment.}

Based on those research findings above mentioned that organizational culture had a positive and significant correlation with organizational commitment, and interpersonal communication had a positive and significant correlation with organizational commitment, then it can predicted that both organizational culture and interpersonal communication simultaneously will create a positive and significant multiple correlation with organizational commitment.

The prediction of that positive and significant multiple correlation between organizational culture and interpersonal communication will be interesting to be empirically investigated, since there no prior research that brought the evidence about it.

\section{RESEARCH HYPOTHESES}

Based on the theoretical framework and prior relevant researches, it can be formulated the hypotheses of this research as follows:

\section{A. There is a positive relationship between organizational culture with organizational commitment.}

\section{B. There is a positive relationship between interpersonal communication with organizational commitment}

C. There is a positive relationship between organizational culture and interpersonal communication simultaneously with organizational commitment.

\section{RESEARCH METHODOLOGY}

This research applied a quantitative approach that used questionnaires for data collecting and statistical techniques for data analysis. The questionnaires were Organizational Commitment Questionnaire (32 items), Organizational Culture Questionnaire (31 items), and Interpersonal Communication Questionnaire (34 items). Those questionnaires scored by 5-point of Likert Scale. The reliability of questionnaires examined by Alpha Cronbach formula (Alpha Coefficients were 0.945, and 0.879 and 0.940 respectively).

This research used 278 teachers of State High-Schools in Merangin District in Jambi Province as the population. By applying Taro Yamane formula $(\mathrm{p}<0.05)$, the sample was 164 teachers randomized selected from the population.

Sequential Explanatory analysis started from Normality Test of the sample, Homogenous Test, Linearity Test, and hypotheses testing used correlation techniques (single and multiple correlations), then continued to applied qualitative analysis for the quantitative findings.

Finally, it applied the SITOREM Method for the purpose of finding specific recommendations to optimize improvement of teachers' organizational commitment [13]. 
Optimization of Enhancement the Organizational Commitment through Developing Organizational Culture and Interpersonal Communication using Sequential Explanatory and SITOREM Methods

\section{RESEARCH RESULT}

\section{A. Normality Test.}

Results of Normality Test used Lilliefors Formula for the scores of questionnaires from research sample, it had been found that all variable scores classified normal ( $\mathrm{Lc}<$ $\mathrm{Lt}$ ) as shown in the table below (notes: Lc is Lilliefors Coefficient calculated from empirical research data, and Lt is the maximum standard of Lilliefors Coefficient):

Table 1. Results of Normality Test $(n=164)$

\begin{tabular}{|l|c|c|l|}
\hline Variables & $\begin{array}{c}\text { Empirical } \\
\text { Data } \\
\text { Calculated } \\
(\mathrm{Lc})\end{array}$ & $\begin{array}{c}\text { Lilliefors } \\
\text { Critical } \\
\text { Value of } \\
0.05(\mathrm{Lt})\end{array}$ & Classification \\
\hline $\begin{array}{l}\text { Organization Culture } \\
\text { to Organizational } \\
\text { Commitment }\end{array}$ & 0.0723 & 0.0870 & Normal $(\mathrm{Lc}<\mathrm{Lt})$ \\
\hline $\begin{array}{l}\text { Interpersonal } \\
\text { Communication to } \\
\text { Organizational } \\
\text { Commitment }\end{array}$ & 0.0823 & 0.0870 & Normal $(\mathrm{Lc}<\mathrm{Lt})$ \\
\hline
\end{tabular}

\section{B. Homogeneous Test.}

Results of Homogeneous Test used the Bartlett Formula for the scores of questionnaires from research sample. It had been found that all variable scores classified homogeneous as shown in the table below (notes: CSc is the Chi-Square Score calculated from empirical research data, and CSt is the maximum standard of Chi-Square Score).

Table 2. Results of Homogeneous Test $(n=164)$.

\begin{tabular}{|l|c|c|c|}
\hline Variables & $\begin{array}{c}\text { Empirical Data } \\
\text { Calculated by } \\
\text { Chi-Square } \\
\text { (CSc) }\end{array}$ & $\begin{array}{c}\text { Critical Value } \\
\text { of Chi-Square } \\
\text { (CSt = 0.05) }\end{array}$ & Classification \\
\hline $\begin{array}{l}\text { Organization } \\
\text { Culture to } \\
\text { Organizational } \\
\text { Commitment }\end{array}$ & 24.653 & 105.267 & $\begin{array}{c}\text { Homogen } \\
\text { (CSc<CSt) }\end{array}$ \\
\hline $\begin{array}{l}\text { Interpersonal } \\
\text { Communication to } \\
\text { Organizational } \\
\text { Commitment }\end{array}$ & 27.354 & 97.351 & $\begin{array}{c}\text { Homogen } \\
\text { (CSc<CSt) }\end{array}$ \\
\hline
\end{tabular}

\section{Linearity Test.}

Results of Linearity Test used the Analysis of Variance for the scores of questionnaires from research sample. It had been found that all variable scores classified linear as shown in the table below (Notes: Fc is the variance scores calculated from empirical research data that compared with maximum critical value of Linearity).

Table 3. Results of Linearity Test $(n=164)$

\begin{tabular}{|l|c|c|c|}
\hline Variables & $\begin{array}{c}\text { Empirical } \\
\text { Data }\end{array}$ & $\begin{array}{c}\text { Critical } \\
\text { Value of }\end{array}$ & Classification \\
\hline
\end{tabular}

\begin{tabular}{|l|c|c|c|}
\hline & $\begin{array}{c}\text { Calculated } \\
(\mathrm{Fc})\end{array}$ & $\begin{array}{c}\text { Linearity } \\
(\mathrm{p}<0.05)\end{array}$ & \\
\hline $\begin{array}{l}\text { Organization Culture } \\
\text { to Organizational } \\
\text { Commitment }\end{array}$ & 0.52 & 1.75 & Linear \\
\hline $\begin{array}{l}\text { Interpersonal } \\
\begin{array}{l}\text { Communication to } \\
\text { Organizational } \\
\text { Commitment }\end{array}\end{array}$ & 0.09 & 1.70 & Linear \\
\hline
\end{tabular}

\section{Hypotheses Testing.}

Results of Hypotheses Testing used the Product-Moment Correlation Formula for the scores of questionnaires from research sample. It had been found that all hypotheses were accepted (the correlations were positive and significant) as shown in the table below.

Table 4. Results of Hypotheses Testing $(n=164)$

\begin{tabular}{|l|c|c|c|c|}
\hline $\begin{array}{l}\text { Correlation } \\
\text { between } \\
\text { Variables }\end{array}$ & $\begin{array}{c}\text { Coefficient } \\
\text { of } \\
\text { Correlation }\end{array}$ & $\begin{array}{c}\text { Empirical } \\
\text { Data } \\
\text { Calculated } \\
\text { for t-value }\end{array}$ & $\begin{array}{c}\text { Critical of } \\
\text { t-value } \\
\text { (t= 0.05) }\end{array}$ & Classificati-on \\
\hline $\begin{array}{l}\text { Organizational } \\
\text { Culture with } \\
\begin{array}{l}\text { Organizational } \\
\text { Commitment }\end{array}\end{array}$ & 0.899 & 5.043 & 3.90 & Significant \\
\hline $\begin{array}{l}\text { Interpersonal } \\
\text { Communication } \\
\text { with } \\
\begin{array}{l}\text { Organizational } \\
\text { Commitment }\end{array}\end{array}$ & 0.795 & 9.660 & 3.90 & Significant \\
\hline $\begin{array}{l}\text { Organizational } \\
\text { Culture and } \\
\text { Interpersonal } \\
\text { Communication } \\
\text { with } \\
\text { Organizational } \\
\text { Commitment }\end{array}$ & 0.895 & 11.290 & 3.05 & Significant \\
\hline
\end{tabular}

\section{E. Analysis by SITOREM Method.}

By using SITOREM Method, the raw data (scores) from all questionnaires were analyzed. It was found that all scores of variables' indicators relatively in a range mid-low category (all scores below category 4 of 5-point Likert Scale). All indicator's scores were ranked (weighted) started from the lowest-score of indicators in each variable. The ranked level of indicator in each variable shown in the figure below. 


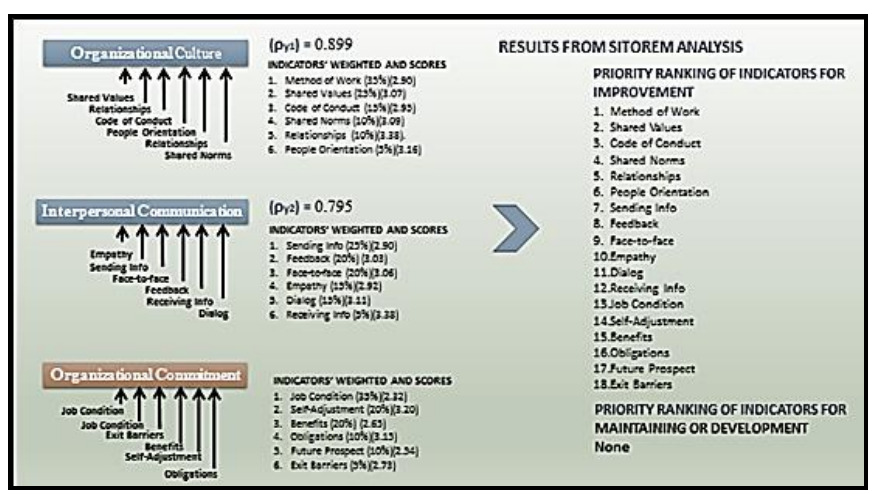

Fig. 1. The Rank-order of Indicators in Each Variable

Based on description in the Figure 1 above, it found that both organizational culture and interpersonal communication had strong relationship (coefficient correlations 0.899 and 0.795 ) with organizational commitment, and then all indicators (see Table 5) which had score below 3.00 should be classified in the priority to improve immediately. The indicators that relatively had higher scores (more than 3.00) will be classified as indicators that should be maintained or developed, and will be programmed on the next occasion.

Based on data analysis as shown in those tables above mentioned, it can be take a conclusion that this research had found the way to increased teachers' organizational commitment in order to improve teaching processes and to achieve educational goals. All the research hypotheses were accepted as follows:

A. There is a positive and significant relationship between organizational culture with organizational commitment $(r=0.899, p<0.01)$,

B. There is a positive and significant relationship between interpersonal communication with organizational commitment $(r=0.795, p<0.01)$, and

C. There is a positive and significant relationship between organizational culture and interpersonal communication simultaneously with organizational

After the hypotheses tested mentioned above, we proposed recommendations based on the results from SITOREM Analysis (see Figure 1). The objectives of the recommendations is to increase teachers' organizational commitment immediately and urgently, as follows: (1) teachers' job condition should be improved (the job redesign which concerns to teamwork will be an alternative method to improve job condition), (2) teachers' future prospect should be well-plan (the formal career planning program for the teacher will be an alternative solution to make future prospect clearer), (3) the benefits program for the teachers should be designed which concerns to retain competence teachers will permanently stay in the organization, and it also become an exit barrier for competence teacher leaving the organization, (4) while the characteristics of teacher's job is a monotonous work, so training the teachers for developing

\section{CONCLUSION AND RECOMMENDATIONS} commitment $(r=0.895, p<0.01)$.

innovative teaching process will be an alternative to solve this problem, (5) there is a need for formalized and to implement the code of conduct for teachers that concerns with moral and ethical aspects of teachers' job description and its environment, and (6) in the area of interpersonal communication, increasing the way of sending information and empathic understanding to others become the most important program. Team building program or teamwork training will become an alternative to improve those interpersonal communication problems.

\section{ACKNOWLEDGMENT}

The recommendations above mentioned, if those are implemented, become "additional big-jobs" addressed to Government Office of Merangin District at Jambi Province. We appreciate for any effort from government office in improving the quality of education through developing organizational commitment, organizational culture and interpersonal communication at state high-schools of Merangin District.

We would appreciate much to the Director and staffs of Graduate Program of Pakuan University for any supports and assistances in finalizing this research paper.

\section{REFERENCES}

1. J. A. Colquitt, J. A. Lepine and M. J. Wesson. Organizational Behavior: Improving Performance in the Workplace. New York: McGraw-Hill, 2015.

2. J. Greenberg,and R.A. Baron. Behavior in Organizations. Upper Saddle River, NJ: Pearson Prentice Hall, 2008.

3. R. Kreitner and A. Kinicki. Organizational Behavior. New York: McGraw-Hill, 2010.

4. E. H. Schein. Organizational Culture and Leadership. San Francisco: John Wiley and Sons, 2010

5. J. R. Schermerhorn, J. G. Hunt, R. N. Osborn, and M. Uhl-Bien. Organizational Behavior. Hoboken: John Wiley and Sons, 2012.

6. R. W. Griffin and G. Moorhead. Organizational Behavior. Mason: South-Western Cengage Learning, 2014.

7. D. Hellriegel and J. W. Slocum. Organizational Behavior. Mason South-Western Cengage Learning, 2010.

8. J. L. Gibson, J. M. Ivancevich, J. H. Donnelly and R. Konopaske. Organizations: Behavior, Structure and Processes. New York: McGraw-Hill, 2012.

9. S. P. Robbins and T. A. Judge. Organizational Behavior. Essex UK: Pearson Education Ltd., 2014.

10. A. Khalik, S. Hardhienata and Widodo Sunaryo. "Relationship between Organizational Culture, Transformational Leadership, and Working Motivation to Organizational Commitment. International Journal of Managerial Studies and Research, Vol. 4, Issue 10 (2016), pp. 93-98.

11. H. Z. Matin, G. Jandaghi., F. H. Karimi, and A. Hamidizadeh (2010). "Relationship between Interpersonal Communication Skills and Organizational Commitment". European Journal of Social Sciences, Volume 13, No. 3 (2010), pp. 34-39.

12. T. A. Siburian (2013). "The Effect of Interpersonal Communication, Organizational Culture, Job Satisfaction, and Achievement Motivation to Organizational Commitment of State High School Teacher in the District Humbang Hasundutan, North Sumatera, Indonesia”. International Journal of Humanities and Social Science, Vol. 3 No. 12 (2013), pp. 89-95.

13. S. Hardhienata. "The Development of Scientific Identification Theory to Conduct Operation Research in Education Management". IOP Conf Series: Material Science and Engineering, Vol. 166 (2017), (doi: 10.1088/1757-899X/166/1/2007). 